\title{
Boron as a Micronutrient in Plants
}

\author{
Esin Oluk (Corresponding author) \\ Ege University, Faculty of Science, Department of Biology, \\ 35100 Bornova-Izmir, Turkey \\ E-mail: esin.oluk@ege.edu.tr \\ Nevruz Latif Akpinar \\ Ege University, Faculty of Science, Department of Biology, \\ 35100 Bornova-Izmir, Turkey
}

\begin{abstract}
The literature concerning the boron, which is highly specific from the point of its mobility besides variability of its optimum-maximum necessity levels even in the same species, and plant relationship is reviewed.
\end{abstract}

Key Words: Boron, Plant, Cell Wall, IAA, Micronutrient

DOI: $10.7176 / \mathrm{JSTR} / 6-02-05$

\section{Bitkilerde Mikrobesleyici Olarak Bor}

\begin{abstract}
Özet
Bu derleme makalede bitkilerde gerek taşınımı, gerekse optimum-maksimum gereksinim seviyelerinin tür içinde bile gösterdiği çeşitlilik açısından son derece özgün bir yere sahip olan bor ve bitki ilişkisi ile ilgili yapılan çalışmalar irdelenmiştir.
\end{abstract}

Anahtar Kelimeler: Bor, Bitki, Hücre Çeperi, IAA, Mikro Besleyici.

\section{Giriş}

Toprakta tuzluluk, su kirliliği ve besleyicilerin eksik veya fazla oluşu gibi etmenlerle kullanılabilir (tarıma elverişli) toprakların azaldığı, böylece hızla artan ve 2050 yılında 9.1 milyara ulaşacağ beslenmesinin tehlikeye girmekte olduğu belirtilmektedir (Zhang and Schwärzel 2017; Stott ve Dercon, 2019). Dolayısıyla, ekilebilir alanlarda maksimum verimi elde edebilmek için bitkilerin optimum beslenme şartlarının belirlenmesi, toprakta var olan minerallerle bitkilerin etkileşiminin aydınlatılması ön plana çıkmaktadır. Bu yönüyle, bitkiler için temel bir mikro besleyici olduğu uzun yıllar önce saptanan (Warington, 1923; Ludbrook, 1942; Bowen ve Gauch, 1965) ve bitki beslenmesi üzerindeki rolü hakkında çelişkili görüşlerin odağı olan borla ilgili çalışmalar da giderek önem kazanmaktadır.

Elementel bor 1808 yılında Fransız Kimyacı Gay-Lussac ile Baron Louis Thenard ve bağımsız olarak İngiliz kimyacı Sir Humpry Davy tarafindan bulunmuştur. Borun kelime kökeni olarak Arapça beyaz anlamına gelen buraq/baurach ve Farsça'da buraj kelimeleri gösterilmektedir. Bu benzetme muhtemelen borun en çok bulunduğu form olan boraksın beyaz renkte olmasından kaynaklanıyor olabilir. Bor, periyodik tabloda B simgesiyle gösterilen, 3A grubunun başında, atom numarası 5 , atom ağırlığı 10,81 , yoğunluğu $2,84 \mathrm{gr} / \mathrm{cm}^{3}$, ergime noktası $2300{ }^{\circ} \mathrm{C}$ ve kaynama noktası $2550{ }^{\circ} \mathrm{C}$ olan, metalle ametal arası yarı iletken özelliklere sahip bir elementtir. Genellikle doğada tek başına değil, başka elementlerle bileşikler halinde bulunur. Doğada yaklaşık 230 çeşit bor minerali vardır (https://www.rsc.org/periodictable/element/5/boron). Oksijenle bağ yapmaya yatkın olması sebebiyle pek çok değişik bor-oksijen bileşimi bulunmaktadır (Nable ve ark., 1997; Tübitak,Bilim-Teknik Dergisi, Mayıs 2002). Bor-oksijen bileşimlerinin genel adı borattır. Bor dünya kabuğunda düzgün dağılmamıştır. Çoğu topraklarda birincil kaynağı tourmalin ve volkan lavlarıdır (Yang ve Jiang, 2012).

Bor bileşikleri, özellikle de boraks binlerce yıldan beri kullanılmaktadır. Babillerin boru kıymetli eşyaların ergitilmesinde, Mısırlıların mumyalamada, Eski Yunanlıların ve Romalıların temizlikte kullandı̆̆ı, yine Mısırlıların, Mezopotamya uygarlıklarının ve Arapların bazı hastalıkların tedavisinde bor'dan yararlandığı bilinmektedir (Eisler, 2007). Hafifliği, gerilmeye olan direnci ve kimyasal etkilere dayanıklılı̆̆1 sebebiyle; plastiklerde, sanayi elyafı 
üretiminde, lastik ve kağıt endüstrisinde, tarımda, nükleer enerji santrallerinde, roket yakıtlarında da kullanılmaktadır (Suri ve Murthy, 2010; Pfeil, 2014; Altuntaş vd., 2017). Camın 1sıyla genleşmesini önemli ölçüde azalttığ1, asite ve çizilmeye karşı koruduğu, titreşim, yüksek 1sı ve 1sı şoklarına karşı dayanıklılığını sağladığı için 1sıya dayanıklı cam gereçleri ve elektronik ve uzay araştırmalarında kullanılacak üstün nitelikli camların üretiminde de önemli yeri vardır (Angeli vd., 2012). Bazı bor bileşikleri yüksek sertlik derecesine sahiptir (Moh skalasına (Klein, 1989) göre sertlik derecesi 9, elmasınki 10); bu sebeple, aşındırıcı ve 1şıkkıran olarak, metalleri ve süper alaşımları kesme, bileme ve cilalamada kullanılmaktadır. Bor bileşikleri tungsten karbüre göre daha yüksek kesme oranına, sürekli-ağır-iş görme kabiliyetine sahiptir ve soğutuculara ihtiyaç duymaz (Garrett, 1998). Yaklaşık 800.000.000 tonluk görünür $\mathrm{B}_{2} \mathrm{O}_{3}$ kapasitesi ile ülkemiz (özellikle Orta Anadolu bölgesi), dünya ekonomik bor rezervinin \%63'üne sahiptir; onu 209.000.000 tonla ABD, 136.000.000 tonla Rusya, 41.000.000 tonla Şili izlemektedir (Bilim Teknik Dergisi, Tübitak, Mayıs 2002) (Şekil 1, Tablo 1).

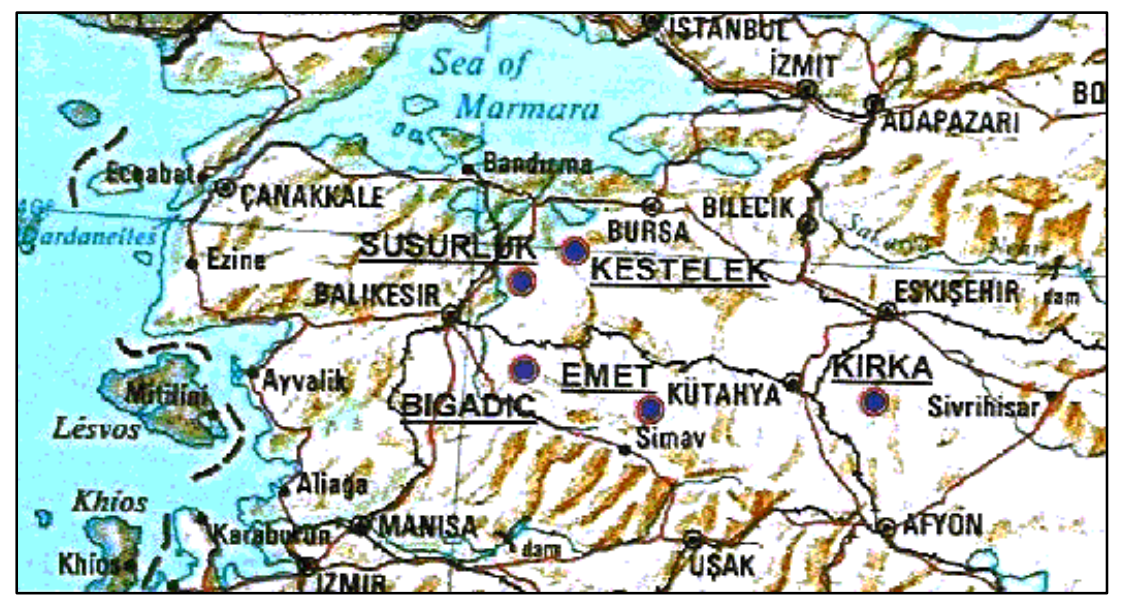

Şekil 1. Türkiye'deki bor madeni rezerv bölgeleri (KIGEM)

Tablo 1- Dünya Toplam Bor Rezervleri (x1000 ton $\mathrm{B}_{2} \mathrm{O}_{3}$ )

\begin{tabular}{|l|c|c|c|c|c|c|c|c|}
\hline \multicolumn{1}{|c|}{ ÜLKE } & $\begin{array}{c}\text { Görünür } \\
\text { Rezerv* }\end{array}$ & $\boldsymbol{\%}$ & $\begin{array}{c}\text { Görünür } \\
\text { Rezerv** }\end{array}$ & $\boldsymbol{\%}$ & $\begin{array}{c}\text { Olası } \\
\text { Rezerv }\end{array}$ & $\%$ & $\begin{array}{c}\text { Toplam } \\
\text { Rezerv }\end{array}$ & $\%$ \\
\hline Türkiye & 803000 & 63 & 375000 & 75.4 & 269000 & 51.3 & 644000 & 63.0 \\
\hline Rusya+ BDT & 136000 & 10.7 & 28000 & 5.6 & 112000 & 21.4 & 140000 & 13.7 \\
\hline ABD & 209000 & 16.4 & 45000 & 9.2 & 60000 & 11.5 & 105000 & 10.3 \\
\hline Çin & 36000 & 2.8 & 27000 & 5.4 & 9000 & 1.7 & 36000 & 3.5 \\
\hline Şili & 41000 & 3.2 & 8000 & 1.6 & 33000 & 6.3 & 41000 & 4.0 \\
\hline Sirbistan & - & - & 3000 & 0.6 & - & - & 3000 & 0.3 \\
\hline Peru & 22000 & 1.7 & 4000 & 0.8 & 18000 & 3.4 & 22000 & 2.0 \\
\hline Bolivya & 19000 & 1.5 & 4000 & 0.8 & 15000 & 2.9 & 19000 & 2.0 \\
\hline İran & - & - & 1000 & 0.2 & 1000 & 0.2 & 2000 & 0.2 \\
\hline Arjantin & 9000 & 0.7 & 2000 & 0.4 & 7000 & 1.3 & 9000 & 1.0 \\
\hline Toplam & 1275000 & 100.0 & 497000 & 100.0 & 524000 & 100.0 & 1021000 & 100.0 \\
\hline
\end{tabular}

*:KİGEM-2008, **:Roskill (Tübitak,Bilim ve Teknik Dergisi, Mayıs, 2002’den düzenlenmiştir)

Ülkemiz topraklarının sahip olduğu bu zengin bor içeriği bitki büyüme ve gelişmesine de kuşkusuz olumlu ya da olumsuz yönde etki etmektedir. Aşağıdaki bölümlerde, adı geçen elementin bitkiler üzerindeki besleyici ya da toksik etkileri; bitkiler tarafından alınımı, taşınımı, hücre içinde dağılımı ve fonksiyonu ülkemiz ve dünya çapında yapılan çalışmalar irdelenerek değerlendirilmiştir.

\section{Bitkiler İçin Mikrobesleyici Olarak Bor}

Bor'un tarımda kullanımı ile ilgili bilgiler sekizinci yüzyıla kadar dayanmaktadır. Bitkinin ihtiyaç duyduğu bor miktarı esas alındığında bir mikro besleyicidir ve mikro besleyiciler arasındaki tek ametal olan elementtir (Shireen vd., 2018). Temel mikro besleyicilerden herhangi birinde olduğu gibi borun da ortamda yeteri kadar bulunmaması, diğer

40 | P a g e 
elementlerin tam veya fazla olması durumunda bile bitkinin gelişimini değiştirir. Bitkilerin ihtiyaç duyduğu bor miktarı oldukça az olmakla beraber, gerek duyulan bu miktarın altı ya da üstü bitkinin gelişimi üzerine olumsuz etki yapmakta ve çoğu zaman gelişim durmaktadır. Yapılan çalışmaların sonuçlarının ortaya koyduğuna göre (Vitosh ve ark., 1994), bitki bor içeriği (kuru maddede) 25-100 ppm arasındaysa optimum, 200 ppm'in üzerine çıktığında toksik olarak kabul edilmektedir; 20 ppm ise bitkilerde eksiklik sınırı olarak belirtilmiştir. Toprakta alınabilir bor miktarı söz konusu olduğunda ise 1 ppm'in altı bor eksikliğine, 5 ppm'in üstü bor toksisitesine neden olabilir (Reisenauer ve ark., 1973). Ayrıca, dayanıklı bitkilerde sulama suyundaki $10 \mathrm{ppm}$ lik bor miktarı toksisite belirtilerini ortaya çıkarırken, duyarlı bitkilerde bu oran 1 ppm e kadar inebilmektedir (Reisenauer ve ark., 1973).

Borun bitkiler için temel oluşunun dışında, kendine özgü olarak, optimum ve toksik seviyeleri arasındaki aralığın dar oluşu, bu elementi tarımsal açıdan önemli ve çalısıllması zor bir parametre haline getirmektedir (Blevins ve Lukaszewski, 1994) Bitki türleri arasında olduğu gibi, aynı türün çeşitleri arasında da bora duyarlılıkta büyük farklılıkların olduğu ve bu farklılıkların bitkilerin bor toksisitesinden fizyolojik olarak farklı düzeylerde etkilenişinden kaynaklandığı belirtilmektedir (Paul ve ark., 1988).

Örneğin mısır (Zea mays L.) bitkisinin sekiz farklı çeşidiyle yapılan bir çalışmada toprağa $10 \mathrm{mg} / \mathrm{kg}$ bor uygulamasına oransal yaş ağırlıktaki cevap Sele çeşidinde \% 54, Furio çeşidinde \% 80 olarak saptanmıştır (Güneş ve ark., 2000). Yine bir başka çalışmada denenen üç buğday çeşidinden biri (Bonza) uygulanan bor toksisitesine $(100 \mathrm{mg} / \mathrm{L}$ bor) tolerant olarak belirlenirken diğeri (Fang 60) hassas olarak ortaya çıkmıştır (Punchana ve ark., 2004). Bu konudaki örnekleri çoğaltmak mümkündür (Taban ve Erdal, 2000).

Öte yandan, tek çeneklilerde kritik bor eksiklik düzeyi $5-10 \mathrm{mg} / \mathrm{kg}$ iken çift çeneklilerde bu miktar 20-70 mg/kg'a kadar çıkmaktadır. Bunun nedeni olarak bu iki gurubun hücre çeperi bileşenlerinin farklılığı (Loomis ve Durst, 1992) gösterilmektedir. Bu fark da dikotillerin hücre çeperinde daha fazla pektin bulunuşuna bağlanmaktadır (Hu ve ark, 1996).

\section{Borun Alınımı, Taşınımı Ve Hücre İçinde Dağılımı}

Borun bitkilerce kullanılabilen formu toprakta çözünebilen, bağımsız, iyonize olmamış $\mathrm{H}_{3} \mathrm{BO}_{3}, \mathrm{~B}(\mathrm{OH})_{3}$ veya iyon halindeki $\mathrm{B}(\mathrm{OH})_{4}{ }^{-}$dır (Hu ve Brown, 1997). Element, topraktan köklerle pasif absorbsiyonla alınır ve bu alınımda toprak pH'ı, nemi ve sıcaklığı da etkilidir (Golberg, 1997). Ortam pH'1 6.3- 6.5 arasında olduğunda bor alınımı en yüksek düzeye ulaşmaktadır. Ancak pH'ın yükselmesiyle birlikte bor alınımı durur. Bunun nedeni olarak pH'ın yükselmesiyle birlikte kullanılabilir borun toprağın organik ve inorganik kolloidleri tarafindan adsorbe oluşu gösterilmektedir (Dugger, 1983; Shorrocks, 1997).

Genel olarak alınımı gerçekleştikten sonra bor, ksilemde transpirasyon ile uçlara doğru taşınmaktadır. Bor taşınımının transpisyona bağlı olması, yaprak uçları ve kenarlarında bor birikiminin nedenini de açıklamaktadır. Borun yapraklarda bu şekilde birikimi kimi hallerde toksik etkilere neden olabilmektedir. Bazı türler bor birikiminin neden olacağı bu toksik etkilerden korunmak için, gutasyon damlaları içinde boru dışarı atma mekanizması geliştirmişlerdir (Scaife ve Turner, 1983). Farklı organlara taşınımın su alımı ve ksilemdeki hareketi ile gerçekleştiği bu bitkilerde (örn. Lycopersicon esculentum) elementin immobil olduğu, ancak farklı türlerde farklı taşınım şekillerinin olabileceği de ileri sürülmektedir (Brown ve Shelp, 1997).

Sözgelimi, bazı bitkilerde (örn. Glycine max), bor için, ksilem ve flöem arasındaki geçişlere dayalı bir proses olabileceği öngörülmektedir (Pate, 1975; Shelp ve ark., 1987). Bu prosese göre hem damarlar arasındaki değişim, hem de mezofil aracılığıyla ksilem ve flöem arasındaki katı hareketini içeren uzun mesafeli taşınım "retranslokasyon" terimi ile açıklanmaktadır(Brown ve Shelp, 1997).

Bazı bitki türlerinin ise bor açısından floem-mobil olduğu, yani borun flöemde taşındığı ileri sürülmektedir (Makkee ve ark., 1985; Picchioni ve ark., 1995). Yapılan denemelerin sonucunda örn. elma, badem ve nektarin gibi predominant fotosentez ürünü poliol (sorbitol) olan türlerde borun sorbitolle bileşik oluşturarak flöemde taşındığı; fistık, ceviz ve incir gibi ilk fotosentez ürününün poliol olmadığı türlerde ise taşınmadığı kanıtlanmıştır Bu konu ile ilgili yapılan bir başka denemede sorbitolce zengin türlere yapraktan uygulanan borun hızla ( $0-15$ gün içerisinde) meyvelere taşındığ 1 , ancak sorbitolce fakir türlerde yaprakta kaldığı bulunmuştur (Brown ve Hu, 1996).

Taşınımı gibi, borun hücre içinde yerleşimi de değişiklik göstermektedir. Bu konuda gelinen son nokta ise suda çözünür borun çoğunun apoplastik bölgede borik asit olarak lokalize olduğu, suda çözünmeyen borun çoğunun ise cis-diol konfigürasyonuna sahip substratlarla özellikle de poliollerle (şeker alkolleriyle) kompleks oluşturduğu yönündedir (Şekil 2) (Makkee ve ark., 1985; Loomis ve Durst, 1992; Matoh ve ark., 1996). 
<smiles>OC[C@@H](O)C(O)C(O)[C@H](O)CO</smiles>

D-mannitol $[\mathrm{P}]$<smiles>CC(O)(O)C1O[PH](O)(O)OC1C(=O)O</smiles>

D-mannitol-3,4-monoborate [BP]

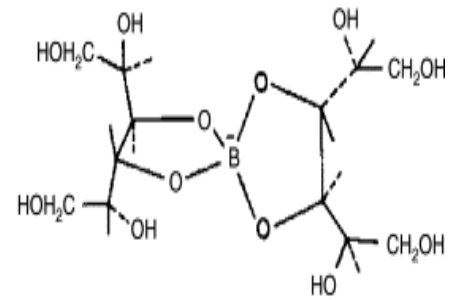

Bis (D-mannitol)-3, 3, 4,, $4^{\prime}$ borate $\left[\mathrm{BP}_{2}\right]$

Şekil 2. Borun bir şeker alkolü olan mannitolle oluşturduğu kompleks.

Özellikle Liliaceae, Amaryllidaceae, Asteraceae, Chenopodiaceae, Apiaceae ve Brassicaceae gibi familyalarda ise suda çözünmeyen borun çoğunun hücre çeperindeki pektinin yapısında bulunan rhamnogalacturanon II (RG-II) ile bileşik oluşturduğu belirtilmektedir (Şekil 3 ve 4) (Ishii ve Matsunaga, 1996; Kobayashi ve ark., 1996; O’Neill ve ark., 1996).

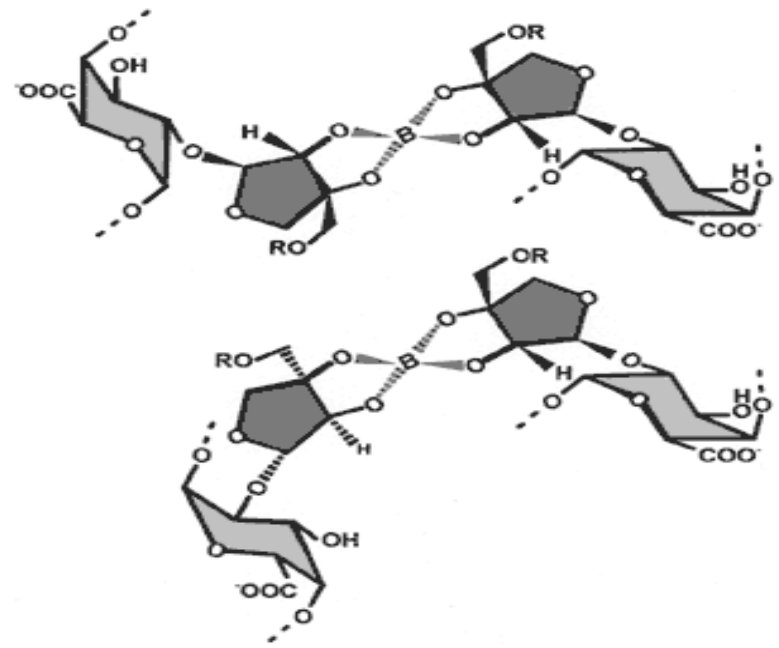

Şekil 3. Borun RG-II monomerlerine borat ester bağlarıyla bağlanışı.

Elementin gerek sitoplazmada gerekse hücre çeperinde kompleks oluşturduğu maddeler polioller ve RG-II ile sınırlı değildir. Şekerler, NAD, fenoller, organik asitler ve bazı polimerler diğer örnekler arasında sayılabilir (Boeseken, 1949; Makkee ve ark., 1985; Loomis ve Durst, 1992; Hu ve Brown, 1997) . 


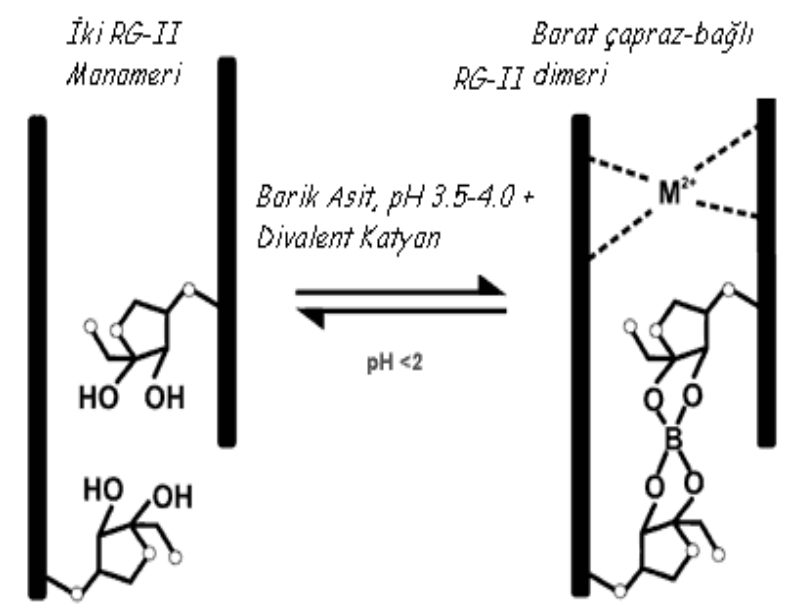

Şekil 4. Borun iki RG-II monomerini çapraz bağladığını gösteren konfigürasyon

\section{Borun Bitkideki İşlevleri}

Borun bitkideki etkileri polen çimlenmesi ve polen tübü uzaması, IAA metabolizması, nükleik asit metabolizması, hücre bölünmesi, hücre çeperi biyosentezi, şeker biyosentezi ve translokasyonu, protein sentezi, membran permeabilitesi gibi çeşitli hücresel proseslerde görülmektedir (Şekil 5) (Parr ve Laughman, 1983; Dugger, 1983; Lovatt, 1985). Elementin fenolik bileşiklerin içeriği ve metabolizmasındaki değişimlerle de ilişkili olduğu (Ruiz ve ark., 1998), yapraklara foliar uygulamayla bu maddelerin azaldığ (Mondy ve Munshi, 1993) bulunmuştur. Ayrıca, borun yüksek 1şıkta fenoliklerin toksik etkisini yok ettiği de bildirilmektedir (Çakmak ve Römheld, 1997). Bor, bitkilerde şekerin hormon faaliyeti üzerindeki etkisini, fotosentez miktarını, köklerin büyümesini ve havadan emilen karbondioksit miktarını artırır. Bir diğer fonksiyonu ise hücre büyümesi ve yapısı üzerine olup, son yapılan çalışmalara göre, askorbat metabolizmasında da önemli bir işleve sahip olduğu saptanmıştır (Lewis, 1980;, Blevins ve Lukaszewski, 1994). Borun Ipomea batatas'ın tüberlerinden saflaştırılan asid fosfataz (E.C. 3.1.3.2.)'da olduğu gibi enzim yapısında bulunmasının yanı sıra (Uehara ve ark., 1974), özel bitki enzimlerinin yapısal bir bileşeni olmadığı (Dugger, 1983) ancak, bitki metabolizmasında bir enzim aktivatörü olarak görev yaptığı (Blevins ve Lukaszewski, 1994) düşünülmektedir.

\section{Bor Eksikliği}

Dünya topraklarında borun genellikle eksikliği görüldüğü ve bitkideki fonksiyonlarının da ortamdan bu maddenin çekilmesiyle belirlendiği için, literatürde genellikle bitkilerde bor eksikliğinin etkilerinin çalışıldığı araştırmalar görülmektedir (Dell ve Huang, 1997; Brown, 2001).

Bitkinin ortamdan sağlayabildiği bor optimumun altına düştüğünde bitkide özgün bor eksikliği belirtileri (bazı anormallikler) gelişmektedir. Bu anormalilerin elementin esas sonucu mu, yoksa esas etkinin ardışık sonucu mu olduğu ise metabolik aktiviteler ve/veya morfolojideki görülebilir değişikliklerin zamanlamasından bulunabilir (Hirsch ve Torrey, 1980). Dolayısıyla eksikliğin ortaya çıkardığı ilk semptomların belirlenmesi önem taşımaktadır. Ancak bunun belirlenmesi de kolay olmayabilir, çünkü fizyolojik değişiklikler çoğunlukla görülmez, gizlidir ve ayrıca borun eksilme sıklığının derecesine bağlı olarak belirtilerin ortaya çıkışı gecikebilir.

Bor eksikliğinin birincil etkileri hücre çeperi ve zarında görülüp, bitki metabolizmasında da ardışık ikincil etkilere sahiptir (Wang ve ark., 2006). Özellikle, bor eksikliğinde artan fenoliklerin IAA oksidazı inhibe etmesiyle meydana gelen oksin seviyesindeki artı̧̧la bor dolaylı olarak lateral tomurcukların apikal dominansiden kurtulmasına neden olacak şekilde bitki büyüme ve gelişmesini etkiler (Dugger, 1983). Bundan başka bor eksikliğinde gövdelerde pektik matriksin sertleşmesinin sonucu olarak mikrofibrillerin düzenlenmesinin bozulduğu ve birikiminin azaldığı ileri sürülmektedir (Starck, 1963). Kök ucu hücrelerinde ise özellikle boyuna çeperlerde düzensiz kalınlaşmalar meydana gelebilir (Kouchi ve Kumatawa, 1975,1976). Bazen golgi cihazının gelişiminde de anormallikler görülür ve bu anormallikler hücre çeperi ve zarı arasındaki salgı vezikülü sayısını arttırabilir. Öyle ki, borun ortamdan alınmasından hemen 6 saat sonra ortaya çıkan çeper kalınlaşmasının sebebi olarak çeper ve membran arasındaki bu salgı vezikülü birikimi gösterilmektedir (Hirsch ve Torrey, 1980). Dolayısıyla borun çeper materyali sentezinde değil, apoplastik bölgede çeper bileşenlerinin ince-yapısal düzenlenmelerinde iş gördüğü üzerine vurgu yapılmaktadır (Matoh, 1997). 


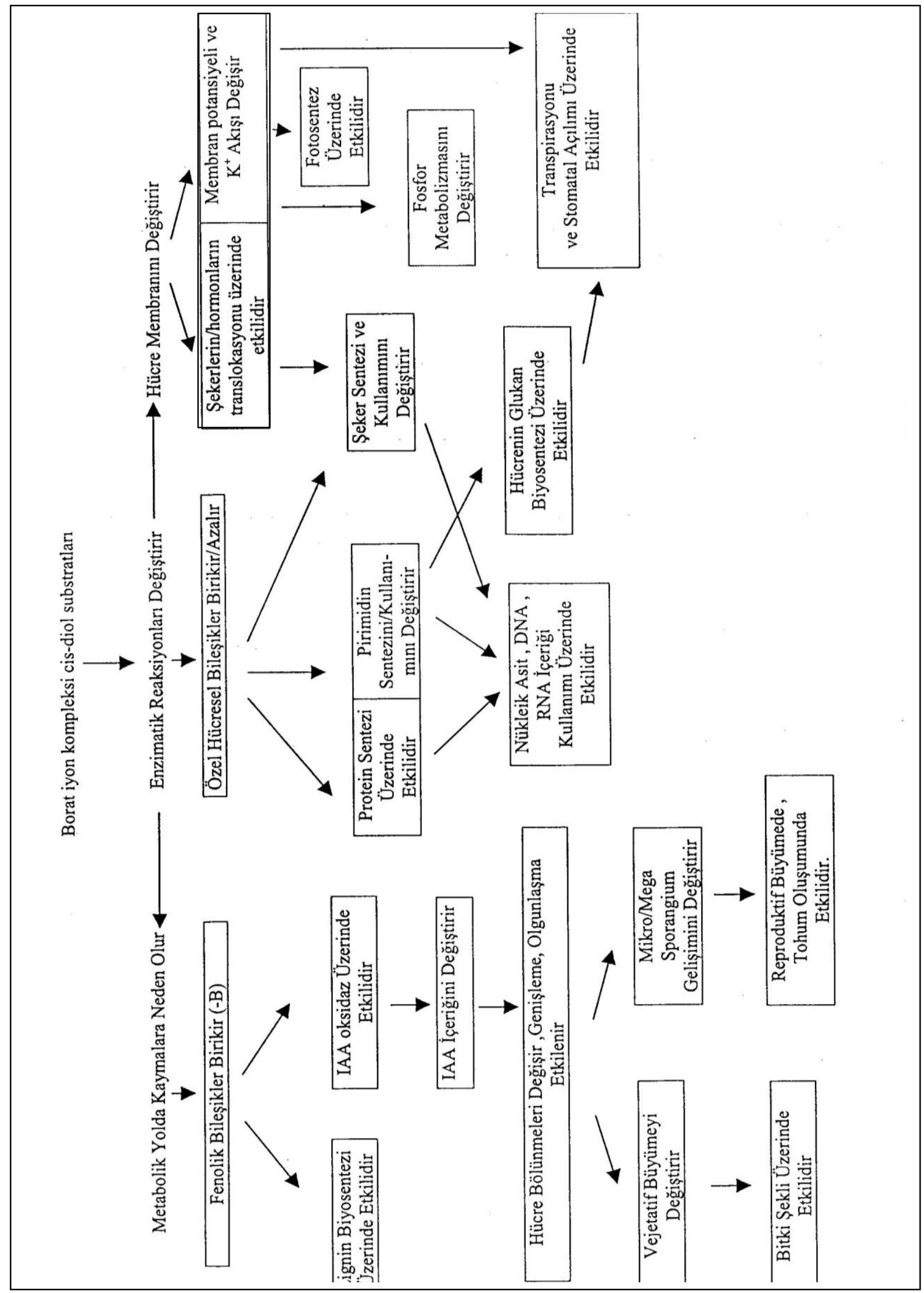


Tüm bunlara bağlı olarak bitkinin fenotipine yansıyan eksiklik etkilerini şöyle sıralayabiliriz. Bor eksikliğinin fenotipteki ilk belirtisi olarak, kök uzaması durur. Bu durumun önceleri hücre bölünmesinden değil, hücresel olgunlaşma ve farklılaşmanın durmasından kaynaklandığı düşünülmüşse de (Skok, 1958), daha sonra hücre bölünmesinin de engellendiği ortaya konmuştur (Dugger, 1983). Bunu müteakiben yavaşlamış ve normal olmayan gelişme ve yeni yaprakların mavi-yeşil renk alışı gözlenir. Ayrıca yaprak ve saplar kırılganlaşır. Bu etkilere paralel olarak büyüme ucu hasar görür; hasar gördüğü noktadan itibaren siyahlaşır ve uç büyümesi durur (Şekil 6) (Latif, 2008; Akçam Oluk ve Latif, 2009).

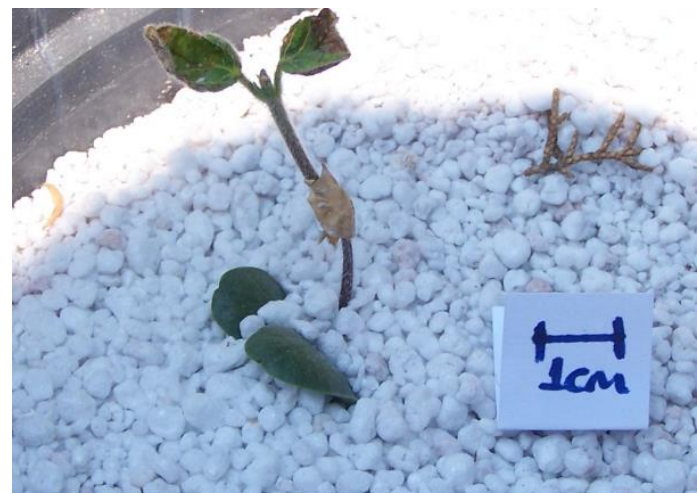

Şekil 6. Bor eksikliğinin 15 günlük soya fasulyesi fidelerinde tepe tomurcuğu ve ilk yapraklar üzerindeki olumsuz etkisi.

$\mathrm{Bu}$ da bitkide yavaş ve bodur gelişime veya bazı durumlarda ölüme sebep olur (Vitosh ve ark., 1994). $\mathrm{Bu}$ tip vejetatif semptomların görülmediği bitkilerde de olmak üzere, bor eksikliğinin sürekliliğinde reprodüktif evre de zarar görür. Çiçeklenme, polen çimlenmesi, bunun paralelinde meyve tutumu ve tohum bağlama engellenebilir (Dell ve Huang, 1997). Bor eksikliğine bağ lı beslenme düzensizliklerinin karakteristik olduğu bitkiler arasında yumru köklü bitkiler (şeker pancarı), meyve ağaçları (özellikle findik), asma, zeytin ve pamuk sayılabilir.

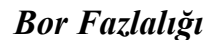

Bor eksikliğinin belirlendiği topraklarda borla gübreleme yoluna gidilebilir. Ancak bu elementin eksik ve toksik seviyeleri arasındaki aralık dar olduğundan gübrelemede dikkatli olunması gerekir.

Nitekim hatalı ve aşırı gübreleme toprakta bor fazlalığını meydana getirebilir. Ana kayanın kendi içeriğinden kaynaklanan bor miktarının yanı sıra bor toksisitesi daha çok kurak ve yarı kurak bölge topraklarında gözlenir (Nable ve ark., 1997). Ayrıca madencilik, endüstriyel atıklar, arıtma çamurları ve çöp kompostları da toprakta bor fazlalığına neden olan etmenlerdir. Yine toprak özelliği (tekstürü) ve sulama suyundaki bor da toprağın bor içeriğinin artmasına neden olur. Özellikle fay hatlarına ve deniz suyuna yakın kuyu sularında, sıcak kaynak ve kaplıca sularında, tuzlu ve alkali toprakların bulunduğu bölgelerdeki yeraltı ve taban sularında yüksek miktarda bor bulunduğu bilinmektedir (Nable ve ark., 1997; Shorrocks, 1997). Sulama suyundaki bora karşı cevaplarına göre bitkiler üç guruba ayrılırlar; 0.3 $1 \mathrm{ppm}$ aralığındaki bor varlığından olumsuz etkilenmeyenler, 1-2 ppm arasında yaşayabilenler ve 2-4 ppm'e dayanıklı olanlar (Keren ve Bingham, 1985) (Tablo 2).

Tablo 2. Bitki türlerinin sulama suyundaki bora toleransları (Keren ve Bingham, 1985'ten düzenlenmiştir).

\begin{tabular}{|l|l|l|}
\hline $\begin{array}{c}\text { Bor Miktarı } \\
(\mathrm{mg} / \mathrm{L})\end{array}$ & Bitki Yanıtı & \multicolumn{1}{c|}{ Örnek Bitki } \\
\hline $0.3-1$ & Hassas & $\begin{array}{l}\text { Persea americana (avokado) Malus domestica (elma) Phaseolus } \\
\text { vulgaris (fasulye) }\end{array}$ \\
\hline $1-2$ & Yarı Dirençli & $\begin{array}{l}\text { Avena sativa (yulaf) Zea mays (mısır) Solanum tuberosum } \\
\text { (patates) }\end{array}$ \\
\hline $2-4$ & Dirençli & $\begin{array}{l}\text { Daucus carota (havuç)Medicago sativum(yonca) Beta vulgaris } \\
\text { (şeker pancar1) }\end{array}$ \\
\hline
\end{tabular}

Hassas türlerde borun floem mobil olduğu, tolerant türlerde ise immobil olduğu belirtilmektedir. İmmobil türlerde bor en çok transpirasyonla yaprak kenarlarında birikir ve buradan gutasyonla atılabileceği gibi 
yaprak yüzeyinde bitkiye fotosentez yapabileceği alan da kalır. Borun floem mobil olduğu hassas türlerde ise bor fazlalığında önce klorofil konsantrasyonu azalır, bunu müteakiben büyüme durur; daha sonra $\mathrm{CO}_{2}$ fiksasyonu azalır ve sonuçta yaprakta fotosentetik alan kaybı meydana gelir. Bu olayların fizyolojik temelinde borun sitoplazmik metabolizmayı bozuşu yatmaktadır (Brown ve Shelp, 1997; Nable ve ark., 1997). Bu bozulmanın mekanizması şöyle açıklanmaktadır; borik asit köklerden yapraklara ksilem elemanları aracılığıyla taşınır (Revan, 1980), bir kısmı çeperdeki yeni sentezlenmiş pektik polisakkarit zincirin RG-II bölgesine bağlanırken kalan kısmın büyük çoğunluğu çeperde herhangi bir liganda bağlanmadan borik asit olarak kalır. Ortamdaki miktarı arttıkça borun köklerden sürgünlere taşınımı da arttı̆̆ için eğer artış devam ederse bor yaprak hücre çeperinde birikecek ve sonuçta sitoplazmaya da sızacaktır. Bu sızıntı fazlalaştığında da sitoplazmik metabolizma zarar göreceği için bor toksisitesini meydana getirecektir (Matoh, 1997). Buradaki tek karanlık nokta borun kök hücre çeperlerinden ksilem elemanlarına nasıl yüklendiğidir.

Bor fazlalığında ayrıca elementin substrata veya enzim-substrat kompleksine bağlanarak 6-fosfoglukonat ve aldolazl (Blevins ve Lukaszewski, 1994) ve kateşol oksidaz, polifenol oksidaz, tirosinaz, peroksidaz ve IAA oksidaz gibi enzimleri (Bohnsack ve Albert, 1977) inhibe ettiği ortaya konmuştur. Bu nedenledir ki bazı bitki türlerinde bor fazlalığında da tıpkı eksikliğinde olduğu gibi IAA birikimi görülebilir (Wang ve ark., 2006; Latif, 2008).

İlaveten Wang ve ark. (2006) tarafından sürgün ucuna ilave bor uygulamasının (10 $\mu \mathrm{M})$, IAA'nın polar taşınımını stimüle ettiği de gösterilmiştir. Olayın mekanizması konuısunda henüz bir netlik olmamakla birlikte, bazı araştırmacılar, borun IAA taşınımı üzerine bu doğrudan ve özgün etkisinin hücre zarındaki IAA alınım- salınım taşıma sistemiyle (Palme ve Galweiler, 1999; Geldner ve ark., 2001) ya da polar IAA akışının korunmasında asal rolleri olan NADH-oksidaz veya H+-ATP-azlarla etkileşme yoluyla olduğu şeklinde açıklamaktadır (Rubery ve Sheldrake, 1974).

Yine yakın dönemde soya fasulyesi ile yapılan bir çalışmada bor fazlalığının $(5 \mathrm{mM})$ kök büyümesini inhibe ettiği belirtilmiştir (Ghanati ve ark, 2004). Araştırıcılara göre, bu kök büyümesindeki azalma, olasıllkla normalde soyada bulunmayan hipodermis tabakasının ortamdaki fazla borla ortaya çıkışı ve ayrıca kortikal hücrelerin çeperinde süberin artışıyla ilişkilendirilmektedir.

Ayrıca, toksik bor derişimlerinde kök ucu meristem hücrelerinin mitotik aktivitesinde bir azalma olduğu; bu mitoz anormalitesinin kendi içinde hücre bölünmesini de etkileyerek sonuçta kök uzama oranını azalttığ 1 belirtilmektedir (Klein ve Brown, 1981; Liu ve ark., 2000). Reid ve ark. (2004)'na göre ise kök ucu bor toksisitesi algılama bölgesi olarak tanımlanmaktadır ve bu bölge fazla bora maruz kaldığında kök uzaması durmaktadır. Choi ve ark. (2007) bu durumu bor fazlalığında kök ucunda şeker azalışı ve bu azalmanın hücre uzaması için gereken ozmotik basıncı değiştirerek kök uzamasını engellediği şeklinde açıklamışlardır. Nitekim daha önceki yıllarda, köklerde biriken aşırı borun kök uzamasını engelleyebileceği Lovatt ve Bates (1984) tarafindan da öngörülmüştür.

Bor toksisitesinin fenotipte ilk belirtileri olarak özellikle yaşlı yapraklarda yaprak uçlarının sararması, klorozis ve yaprak kenarlarının aşırı derecede yanması gözlenir (Şekil. 7) (www.agnet.org 14.02.2008).

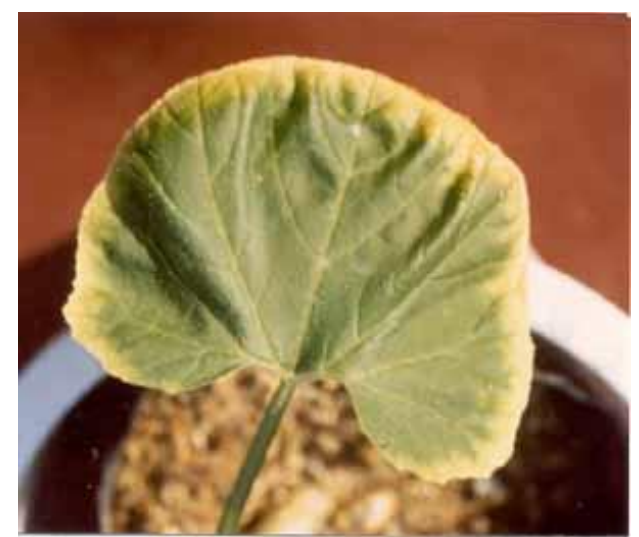

Şekil 7. Bor fazlalığının kavun (Cucumis melo L.) bitkisinde meydana getirdiği yaprak kenarı yanıklığı.

Semptomlar daha sonra orta damara kadar yayılır. Bor miktarının 5 ppm den fazla olması durumunda kökte yanma meydana gelip, ani bitki ölümü gözlenebilir. Ayrıca yaprakların kıvrılması, kabuk nekrozları, genç gövdelerde uç yanıklığı, yaprak aksillerinde aşırı zamklanma ve gövde ile petiyoller arasında kahverengi mantarsı lezyonların görülmesi de semptomlar arasında sayılabilir (Nable, 1991; Vitosh ve ark., 1994; Brown, 2001). 
Bora tolerant bitkiler ortamdaki bordan kaçınmak amacıyla bazı mekanizmalar geliştirirler. Örn. bazı bitkiler kök sistemlerinde yer alan fiziksel bir bariyer vasıtasıyla veya köklerden boru uzaklaştırmaya yarayan pompa mekanizmasıyla fazla bordan kaçınabilirler; ya da kimi bitkiler kök sistemlerindeki bir takım kimyasal reaksiyonlar aracılığıyla rizosfer $\mathrm{pH}$ ını değiştirerek bor alınımını engelleyebilirler. Ayrıca derişimin yüksek olduğu toprak katmanlarında kimi bitkiler yüzeysel kökler oluşturarak bor toksisitesine karşı kendilerini koruyabilirler (Cartwright ve ark., 1987; Rahtjen ve ark., 1987; Paul ve ark., 1992).

Bitkilerin kendilerini koruyamayacak seviyedeki bor fazlalığının giderilmesi için toprak pH'ına bağlı olarak kireçleme yapılabilir. İlk ve en etkili mücadele budur. Bundan başka toprak iyi drene edilerek borsuz sulama suyu ile yıkanabilir ya da ara bitki olarak topraktan çok bor kaldıran türler yetiştirebilir (Babaoğlu ve ark., 2004). Bor toksisitesiyle mücadele ile ilgili yapılan çalışmalarda çinkonun borun toksik etkisini azaltıcı etkisinin bulunduğu gözlenmiştir. Aynı şekilde kalsiyum varlığında da bor alımı yavaşlar. Sodyum ve klorürün de benzer etkilerinin olduğu ileri sürülmüştür (Nable ve ark., 1997).

\section{Sonuç Ve Tartışma}

Yukarıda irdelemeye çalıştığımız şekliyle bor, bitkideki etkileri açısından mikrobesleyiciler arasında özgün yönünü korumaktadır. Son yıllarda özellikle fazlalığıyla ilgili yapılan araştırmalar ve literatür özetlerinden (önceden beri de vurgulanan şekliyle) elementin eksiklik ve toksiklik etkilerinin benzer olduğu anlaşılmaktadır. Bu çalışmada, son yıllarda yapılan çalışmaların ışı̆̆ı altında, borun netlik kazanan fizyolojik etki mekanizmaları ortaya konmaya çalışılmışsa da, yapılan taramalarda, hemen hemen her araştırmada borun bitkilerdeki rolünün hala soru işaretlerine maruz kaldığı yönünde ifadelere rastlanmıştır. Bu soru işaretlerinin ortadan kalkmasında yani, bitki büyüme süreçleri ve fizyolojisi üzerine rolünün belirlenmesinde, elementin hücre zar yapısı ve fonksiyonları ile çeper yapısındaki görevlerini aydınlatan çalışmalara ihtiyaç duyulduğu belirtilmektedir.

Öte yandan, ülkemiz dünyada bor rezervi açısından en zengin ülke olarak özellikle Orta Anadolu bölgesinde bor fazlalığının söz konusu olabileceği topraklara sahiptir. Bu yönüyle borun tarımsal öneme sahip bitkiler (özellikle buğdaygiller) üzerine etkilerinin araştırıldığı yeni çalışmalara duyulan gereksinim açıktır. Ancak, bu çalışmada yaptı̆̆ımız literatür taramasından ülkemizde konuyla ilgili araştırmaların artan bir ilgiyle sürdüğü anlaşılmaktadır (Karabal ve ark., 2003; Gülümser ve ark., 2005; Yorgancılar ve Babaoğlu, 2005; Akçam Oluk ve ark., 2006; Akçam Oluk ve Latif, 2009; Akçam Oluk vd., 2012).

\section{Kaynakça}

Akçam Oluk E., Acar O., Demirbaş S., Duran H., Atik E. \& Görkem H.N. 2012. Alteratıons in ant10xidative enzyme activities caused by boron toxicity in two tomato culture varieties, Fresenius Environmental Bulletin, 21(2), 290-294.

Akçam Oluk, E., Demiray, H. \& Yardım, D. (2006). Bor Fazlalığının Ayçiçeği (Helianthus annuus L.cv.Sambro No.5) Bitkisinin in vitro Koşullarda Kök Gelişimi ve Anatomisi Üzerine Etkileri, Ege Üniversitesi Ziraat Fak. Derg., 43(2), 145-152.

Akçam Oluk, E. \& Latif, N. (2009). Soya Fasulyesinin (Glycine max L. var. Umut 2002) Büyümesi ve Gelişimi Üzerine Bor Elementinin Etkileri. EUFBED Fen Bil Enst Derg 1(1), 27-38.

Altuntaş, E., Karaoğul, E. \& Mehmet, A. (2017). Effect of boron compounds on the thermal and combustion properties of wood-plastic composites. 18. 247-250. 10.18182/tjf.308944.

Angeli, F. et al. (2012). Effect of Temperature and Thermal History on Borosilicate Glass Structure. Physical Review B. 85. 10.1103/PhysRevB.85.054110.

Babaoğlu, M. et al. (2004). Gypsophila sphaerocephala Fenzl ax Tchihat.: A Boron Hyperaccumulator Plant Species That May Phytoremediate Soils with Toxic B Levels, Turk J Bot, 28, 273-278.

Bilim ve Teknik Dergisi, TUBITAK. (2002). Mayıs Sayısı. 
Blevins, D.G. \& Lukaszewski, K.M. (1994). Proposed Physiologic Functions of Boron in Plants Pertinent to Animal and Human Metabolism, Environ Health Perspect, 102 (Suppl 7), 31-33,

Boeseken, J. (1949). The Use of Boric Acid for the Determination of the Configuration of Carbohydrates. In: Advances in carbohydrate chemistry V4. Eds.WWPigman andMLWolfrom, pp 189-210.Academic Press, New York.

Bohnsack, C.W. \& Albert, L.S. (1977). Early Effects of Boron Deficiency on Indolacetic acid Oxidase Levels of Squash Root Tips, Plant Physiol, 59(6),1047-1050.

Bowen, J.E. \& Gauch, H.G. (1965). Essentiality of Boron for Dryopteris dentata and Selaginella apoda, American Fern Journal, 55,67-73.

Brown, P.H. \& Hu,H. (1996). Phloem Mobility of Boron is Species Depent. Evidence for Phloem Mobility in Sorbitol Rich Species. Ann Bot, 77, 497-505.

Brown, P.H. \& Shelp, J.B. (1997). Boron Mobility in Plants, Plant and Soil, 193,85-101.

Brown, P.H. (2001). Transient Nutrient Deficiencies and Their Impact on Yield - A Rationale For Foliar Fert1lizers, Acta Hort (ISHS), 564,217-223.

Choi, E. et al. (2007). The Mechanism of Boron Tolerance for Maintanance of Root Growth in Barley (Hordeum vulgare L.), Plant, Cell and Environment, 30, 984-993.

Cartwright, B. et al. (1987). Rathjen A.J., Sparrow, D.H.B., Paul, J.G. and Zarcinas, B.A., Boron Tolerance in Australian Varieties of Wheat and Barley, In: Genetic Aspects of Pant Mineral Nutrition. Eds. H W Gabelman and B C Loughman (eds.). p 139-151. Martinus Nijhoff, Dordrecht, The Netherlands.

Caucci, S. \& Hettiarachchi, H. (2017). Wastewater irrigation in the Mezquital Valley, Mexico: solving a century-old problem with the Nexus Approach. Proceedings of the International Capacity Development Workshop on Sustainable Management Options for Wastewater and Sludge, Mexico, 15-17 March 2017. Institute for Integrated Management of Material Fluxes and of Resources (UNU-FLORES).

Çakmak, I. \& Römheld, V. (1997). Boron Deficiency-Induced Impairments of Cellular Functions in Plants, Plant and Soil, 193,71-83.

Dell, B. \& Huang, L. (1997). Physiological Response of Plants to Low Boron, Plant and Soil, 193, 103-120.

Dugger, W.M. (1983). Boron in Plant Metabolism, In: Encylopedia of Plant Physiology, New Series (A.Lauchli and Bieleski R.L. eds.), Vol 15B, Sprienger Verlag, Berlin, pp.626-650.

Eisler, R. (2007). Eisler's Encyclopedia of Environmentally Hazardous Priority Chemicals. The Netherlands.

Garrett, D. (1998). Borates: Handsbook of Deposits, Processing, Properties and Use, San Diego Academic Pres., USA.

Geldner, N. et al. (2001). Auxin Transport İnhibitors Block PIN1 Cycling and Vesicle Trafficking, Nature, 413,425-428.

Gemici, M. et al. (2002). The Effects of the Boron Aplication on Indole-3-Acetic Acid Levels in Triticum durum Desf. cv. Gediz Seedlings, C.Ü. Fen-Edebiyat Fakültesi Fen Bilimleri Dergisi, 23,2 . 
Ghanati, F., Morita, A. \& Yokota, H. (2004). Deposition of Suberin in Roots of Soybean Induced by Excess Boron. Plant Science, 168(2), 397-405.

Golberg, S. (1997). Reaction of Boron With Soils, Plant and Soil, 193,35-48.

Gülümser, A., Odabaş, M.S. \& Özturan, Y. (2005). Fasulyede (Phaseolus vulgaris L.) Yapraktan ve Topraktan Uygulanan Farklı Bor Dozlerının Verim ve Verim Unsurlarına Etkisi, Akdeniz Üniversitesi Ziraat Fakültesi Dergisi, 18(2), 163-168.

Güneş, A. et al. (2000). Türkiye'de Yaygın Olarak Yetiştirilen Misır (Zea Mays L.) Çeşitlerinin Bor Toksisitesine Duyarlılıkları, Turk J Agric For, 24, 277-282.

Hirsch, A.M. \& Torrey, J.G. (1980). Ultrastructural Changes in Sunflower Root Cells in Relation to Boron Deficiency and Added Auxin, Can J Bot, 58,856-866.

Hu, H., Brown, P. H. \& Labavitch, J. M. (1996). Species Variability in Boron Requirement İs Correlated With Cell Wall Pectin. J Exp Bot, 47, 227-232.

Hu, H. \& Brown, H.P. (1997). Absorption of Boron by Plant Roots, Plant and Soil, 193,49-58.

Ishii, T. \& Matsunaga, T. (1996). Isolation and Characterisation of a boron-rhamnogal acturonan-II Complex from Cell Walls of Sugar Beet Pulp, Carbohydr Res, 284,1-9.

Karabal, E., Yücel, M. \& Öktem, H. A. (2003). Antioxidant Responses of Tolerant and Sensitive Barley Cultivars to Boron Toxicity, Plant Science, 164, 925-/933.

Keren, R. \& Bingham, F.T. (1985). Boron in Water, Soils and Plants, Adv Soil Sci, 1,230-276

KIGEM. (2008). Kamu işletmeciliğini geliştirme merkezi (Kurum 2014’te kapatılmıştır).

Klein, C. (1989). Minerals and Rocks: Exercises in Crystallography, Mineralogy, and Hand Specimen Petrology. Copyright,John Wiley \& Sons. Reprinted by permission of John Wiley \& Sons, Inc.

Klein R.M. \& Brown S.J. (1981). Effect of Borate Excess and Calcium Ion on Mitosis of Pea RootTip Meristem Cells. Environmental and Experimental Botany, 22, 199-202.

Kobayashi, M., Matoh, T. \& Azuma, J.I. (1996). Two Chains of Rhamnogalacturonan II are CrossLinked by Borate-Diol Ester Bonds in Higher Plant Cell Walls, Plant Physiol, 110,1017-1020.

Kouchi,H. \& Kumatawa,K. (1975). Anatomical Responses of Root Tips to Boron Deficiency. II. Effect of Boron Deficiency on Cellular Growth and Devolepment in Root Tips. Soil Sci Plant Nutr, 21,137-150

Kouchi,H. \& Kumatawa,K. (1976). Anatomical Responses of Root Tips to Boron Deficiency. III. Effects of Boron Deficiency on Sub-Cellular Structure of Root Tips, Particularly on Morphology of Cell Wall and Its Related Organelles, Soil Sci Plant Nutr, 22,53-71.

Latif, N. (2008). Soya Fasulyesinin (Glycine max L. var. Umut 2002) Gelişimi Üzerine Bor Elementinin Etkileri, Ege Üniversitesi Fen Bilimleri Enstitüsü Yüksek Lisans Tezi, 60 s.

Lewis, D.H. (1980). Boron, Lignification and the Origin of Vascular Plants- A Unified Hypothesis, New Phytol, 84,209-229.

Liu D. et al. (2000). Effects of Boron İons on Root Growth and Cell Division of Broadbean (Vicia faba L.). Israel Journal of Plant Science, 48, 47-51.

Loomis, W.D. \& Durst, R.W. Chemistry and Biology of Boron, BioFactors, 3:229-239, (1992). 
Lovatt, C.J. and Bates, L.M. (1984). Early Effects of Excess Boron on Photosynthesis and Growth of Cucurbita Pepo. J Exp Bot, 35,297-305.

Lovatt, C.J. (1985). Evolution of Xylem Resulted in a Requirement for Boron in the Apical Meristems of Vascular Plants, New Phytol, 99,509-522.

Ludbrook, W.V. (1942). Effects of Various concentrations of Boron on the Growth of Pine Seedlings, Journal of Australian Institute of Agricultural Science, 8,112-114.

Makkee, M., Kiebom, A.P.G. \& Van Bekkum, H. (1985). Studies on Borate Esters III. Borate esters of D-mannitol, D-glucitol, D-fructose and D-glucose in Water Recl Trav Chim Pays-Bas, 104,230-235.

Matoh, T., Kawaguchi, S. \& Kobayashi, M. (1996). Ubiquity of Borate-rhamno-galacturan II Complex in the cell walls of Higher Plants. Plant Cell Physiol, 37,639-642.

Matoh, T. (1997). Boron in Plant Cell Walls. Plant and Soil, 193,59-70.

Mondy, N.I. \& Munshi, C.B. (1993). Effects of Boron on Enzymatic Discoloration and Phenolic and Ascorbic Acid Contents of Potatoes, J Agric Food Chem, 41, 554-556.

Nable, R.O. (1991). Distribution of Boron within Barley Genotypes with Differing Susceptibilities to Boron Toxicity. J Plant Nutr, 14, 453-461.

Nable, R.O., Banuelous, S.G. \& Paull, G.J. (1997). Boron Toxicity. Plant and Soil, 198,181-198.

O’Neill, M.A. et al. (1996). Rhamnogalacturonan-II, a Pectic Polysaccharide in the Walls of Growing Plant Cells, Forms a Dimer that is Covalently Cross-linked by a Borate Ester, J Biol Chem, 271,22923-22930.

Palme, K. \& Gälweiler L. (1999). PIN-Pointing the Molecular Basis of Auxin Transport. Curr Opin Plant Biol, 2,375-381.

Paull, J.G., Cartwright, B. \& Rathjen, A.J. (1988). Responses of Wheat and Barley Genotypes Toxic Concentrations of Soil Boron. Euphytica, 39, 137-144.

Paull, J.G. et al. (1992). Response of Annual Medics (Medicago spp.) and Field Peas (Pisum sativum) to High Concentration of Boron: Genetic Variation and The Mechanism of Tolerance. Aust J Agric Res, 43,203-213.

Parr, A.J. \& Loughman, B.C. (1983). Boron and Membrane Function in Plants, in: Metals and Micronutrients. Uptake and Utilization by Plants. Eds. D.A. Robb and W.S. Pierpoint. pp:87-107, Academic Pres, New York.

Pate, J. S. (1975). Exchange of Solutes Between Phloem and Xylem and Circulation in the Whole Plant, In Encyclopedia of Plant Physiology, new series. Vol. 1, Transport in Plants. I. Phloem Transport. Eds. M H Zimmermann and J A Miburn. pp 451-473. Springer- Verlag, New York.

Pfeil, Mark. A. (2014). Solid amine-boranes as high performance hypergolic hybrid rocket fuels. Open Access Dissertations. 347. https://docs.lib.purdue.edu/open_access_dissertations/347.

Picchioni, G.A., Weinbaum, S.A., \& Brown, PH. (1995). Retention and The Kinetics of Uptake and Export of Foliage-applied, Labeled Boron by Apple, Pear, Prune, and Sweet Cherry Leaves. Journal of the American Society of Horticultural Science, 120, 28-35

Punchana,S., Jamjod, S. \& Rerkasem, B. (2004). Response to Boron Toxicity in Boron Efficient and Inefficient Wheat Genotyps. 4. Int. Crop Sci. Cong., Sept. Brisbane, Australia. 
Rahtjen, A.J. et al. (1987). Breeding for Tolerance of Mineral Toxicities in Australian Cereals with Special Reference to Boron, in:Priorities in Soil/Plant Relations Reserch for Plant Production. Eds. P.G.E. Seaerle and B.G. Davey. p 111-130. School of Crop Sciences, The University of Sydney, Australia.

Reid R.J. et al. (2004). A Critical Analysis of the Causes of Boron Toxicity in Plants, Plant Cell and Environment, 25, 1405-1414.

Reisenauer, H. M., Walsh, L. M. \& Hoeft, R. G. (1973). Testing Soils for Sulphur, Boron, Molybdenum, and Chlorine, In: Soil Testing and Plant Analysis. L. M. Walsh and J. D. Beaton (Eds.), Soil Science Society of America. Madison, Wisconsin USA, pp. 173-200.

Revan, J.A. (1980). Short and Long - Distance Transport of Boric Acid in Plants. New Phytol, 84,231-249.

Rubery, P.H. \& Sheldrake, A.R. (1974). Carrier Mediated Auxin Transport. Planta, 188,101-121.

Ruiz, J.M. et al. (1998). Relationship Between Boron and Phenolic Metabolism in Tobacco Leaves. Phytochemistry, 48,269-272.

Scaife, A. \& Turner, M. (1983). Diagnosis of Mineral Disorders of Plants. Vegetables, 2, 96.

Shelp, B.J., Shattuck, V.I. .\& Proctor, J.T.A. (1987). Boron Nutrition and Mobility, and Its Relation to Elemental Composition of Greenhouse Grown Root Crops. II. Radish. Comm Soil Sci Plant Anal, 18,203-219.

Shireen, F. et al. (2018). Boron: Functions and Approaches to Enhance Its Availability in Plants for Sustainable Agriculture. International journal of molecular sciences, 19(7), 1856. doi:10.3390/ijms19071856.

Shorrocks,V.M. (1997). The Occurence and Correction of Boron Deficiency. Plant and Soil,193,121148.

Skok, J. (1958). The role of Boron in the Plant Cell, in: Trace Elements. Eds. C.A. Lamb, O.G. Bentley and, J.M., Beattie p:227-243, Academic Press, London.

Starck, J.R. (1963). Effects of Boron on Cell Wall Structure of Sunflower. Acta Soc Bot Pol, 32,619623.

Stott T. \& Dercon, G. (2019). Impact of climate change on land, water and ecosystem quality in polar and mountainous regions: gaps in our knowledge. Climate Research, 77 (2), 115-138.

Suri, A.K. \& Murthy, T.S.R.Ch. (2010). Development of Boron -based Materials for Nuclear Applications. BARC Newsletter,313, 14-22.

Taban, S. \& Erdal,İ. (2000). Bor Uygulamasının Değişik Buğday Çeşitlerinde Gelişme ve Toprak Üstü Aksamda Bor Dağılımı Üzerine Etkisi, Turk J Agric For, 24, 255-262.

Uehara, H. et al. (1974). Regulation of Neutral Protease Activity in Bacillus subtilis: Transformation of High Protease Activity. Journal of Bacteriology, 119(1), 82-91.

Vitosh, M.L., Warncke, D.D. \& Lucas, R.E. (1994). Boron, Secondary and Micronutrients for Vegetables and Field Crops. Michigan Extension Bulletin, E-486.

Wang, G., Römheld,V.,Li, C. \& Bangerth, B. (2006). Involment of Auxin and CKs in Boron Deficiency Induced Changes in Apical Dominance of Pea Plants Journal of Plant Physiology, $163,595-600$. 
Warington, K. (1923). The Effects of Boric Acid and Borax on The Broad Bean And Certain Other Plants. Ann Bot, 37, 457-466.

Yang, S-Y. \& Jiang, S-Y. (2012). Chemical and boron isotopic composition of tourmaline in the Xiangshanvolcanic-intrusive complex, Southeast China: Evidence for boron mobilizationand infiltration during magmatic-hydrothermal processe. Chemical Geology 312-313, 177-189.

Yorgancılar, M. \& Babaoğlu, M. (2005). Buğday Çeşitlerinde Borun Çimlenme Üzerine Etkisinin in vitro ve Saksı Şartlarında Araştırılması. S. Ü. Ziraat Fakültesi Dergisi, 19(35), 109-114.

Zhang, L. \& Schwärzel, K. 2017. China's Land Resources Dilemma: Problems, Outcomes, and Options for Sustainable Land Restoration. Sustainability, 9(12), 1-13.

www.agnet.org 14.02.2008'de indirilmiştir.

www.rsc.org/periodic-table/element/5/boron 20.11.2019'da indirilmiştir. 